\title{
Body Mass Index and Physical Fitness Profile of Physical Education Students
}

\author{
Aridhotul Haqiyah*, Memet Muhamad, Bujang Bujang, Apta Mylsidayu, Elly Diana Mamesah \\ Physical Education \\ Universitas Islam 45 Bekasi \\ Bekasi, Indonesia \\ *aridhotulhaqiyah@unismabekasi.ac.id
}

\begin{abstract}
The purpose of this study was to determine the profile of body mass index and physical fitness level of the students. The research method used is descriptive quantitative by using body mass index and physical fitness test. The population in this research is the 116 students of physical education program of Universitas Islam 45 Bekasi force 2017/2018. The sampling technique used is random sampling with a number of 77 students. Data analysis technique using descriptive technique percentage. There are several test instruments used in this study, there are: 1) body mass index measurement, 2) sprint 50 meters, 3) Illinois agility run test, 4) sit up, 5) pull up, 6) vertical jump, 7) sit and reach, 8) push up, 9) eye-hand coordination test and 10) bleep test. Based on the results of the calculation and data analysis it can be concluded that: (1) body mass index test results showed 1 or $1.3 \%$ of students who are in the category weightless, 58 or $75.3 \%$ of students in the category of normal weight, 10 or $13 \%$ students in the category of overweight and 8 or $10.4 \%$ of students in the obesity category, (2) physical fitness test results showed that $13.28 \%$ in very good category, $15.58 \%$ in good category, $23.38 \%$ in the medium category, 24.39 in the category of less, and $23.38 \%$ in very less category. Based on result body mass index students in normal level and physical fitness in less category.
\end{abstract}

Keywords: body mass index, physical fitness, physical education student

\section{INTRODUCTION}

Based on the Government Regulation of the Republic of Indonesia Number 66 of 2010 on Amendment to Government Regulation Number 17 of 2010 concerning Management and Implementation of Education and the Regulation of the Minister of National Education Number 34 Year 2010 on the Pattern of New Student Admission of Undergraduate Program at Higher Education held by the Government, freshmen of undergraduate programs at universities through a national selection pattern conducted by all universities together to be followed by prospective students from all over Indonesia [1,2].

The Program Study of Physical Education in Universitas Islam 45 Bekasi was developed with the vision of producing professional physical, sports and health. Mastering Science and technology based on "STAF" (Siddiq, Tabligh, Amanah, Fathonah), and able to develop entrepreneurship in sports and recreation in 2019. While the missions to be achieved include: (1) Conducting the latest education to produce educational staff at primary, secondary, and upper level, (2) Developing the quality of graduate competence through religion, science, technology, art, sport and culture (3) Empowering the academic community, support staff, stakeholders and the community to create an optimum and conducive academic atmosphere, (4) Improving work ethic of organization, discipline and leadership for academic community and support staff toward globalization through clean and transparent management .

The objectives of the Physical Education Program, Islamic University 45 Bekasi are directed towards a fairly comprehensive objective in generic abilities in the field of Physical Education Health and Recreation required by formal and non-formal education institutions in the community, among others: (1) Produce graduates who have academic ability and can apply, develop and broaden the science of sport, (2) Produce graduates who are able to conduct research and development of sports science whose results can be implemented to meet the needs of the community, (3) Produce graduates who are able to devote or implement knowledge and skills in the field of education body to society.

One of the goals and strategies for the achievement of the physical education program is to produce graduates with the ability as a well-educated educator in the field of physical health and recreation education and able to perform their duties and obligations professionally and disseminate knowledge on various types and levels of education. Before becoming an educator, a physical education course student needs to have good physical fitness so that in the learning process can achieve optimal results. Physical fitness of physical education teachers will greatly affect teacher competence and performance.

To optimize graduates, the program of physical education, Universitas Islam 45 Bekasi develops several physical and skill test instruments that can identify physical fitness and skills of new student candidates, namely: health test and physical fitness test. The series of tests are conducted to capture prospective teacher of physical education according to expected criteria.

In medical tests, measurements of body height, body weight and body mass index, blood pressure check and eye examination were done using Ishihara colour blindness test. While on the fitness test include : sprint 50 meters, Illinois agility run test, sit-ups, pull-ups, vertical jumps, sit and reach, 
push up, hand-eye coordination test and cardiorespiratory endurance test with bleep test.

One of the test items that exist on a health test is the measurement of body mass index. Body mass index (BMI) is the ratio of weight to high standard and is often used as a general health indicator. Body mass index (BMI) is a simple index of weight-for-height that is commonly used to classify overweight and obesity in adults. It is defined as a person's weight in kilograms divided by the square of his height in meters $(\mathrm{kg} / \mathrm{m} 2)$ [3,4]. BMI rates between 18.5 and 24.9 are considered normal for most adults [5]. Higher BMI may indicate overweight or obese [6]. This method can estimate body fat, but it cannot be interpreted as a definite percentage of body fat.

\section{TABLE I. PRACTICAL GUIDELINES FOR ADULT NUTRITION STATUS} MONITORING

\begin{tabular}{|l|l|l|l|}
\hline \multicolumn{1}{|c|}{ Category } & \multicolumn{1}{c|}{ Explanation } & \multicolumn{1}{c|}{ Female } & \multicolumn{1}{c|}{ Male } \\
\hline Less Weight & $\mathrm{IMT}=<90 \%$ & $<18.9$ & $<20.2$ \\
\hline Ideal Wight & $\mathrm{IMT}=100 \%$ & 21 & 22.5 \\
\hline $\begin{array}{l}\text { Normal } \\
\text { Weight }\end{array}$ & $\mathrm{IMT}=90-110 \%$ & $18.9-23.1$ & $20.2-24.7$ \\
\hline Over Weight & $\mathrm{IMT}=110-120 \%$ & $23.1-25.2$ & $24.7-27.0$ \\
\hline Obesity & $\mathrm{IMT}=\mathrm{m}>120 \%$ & $>25.2$ & $>27$ \\
\hline
\end{tabular}

Physical fitness is defined as a set of attributes that people have or achieve that relates to the ability to perform physical activity. It is also characterized by (1) an ability to perform daily activities with vigour, and (2) a demonstration of traits and capacities that are associated with a low risk of premature development of hypokinetic diseases [7]. Physical fitness is a physical condition that describes the potential and physical ability to perform certain tasks with optimal results without showing significant fatigue [8-11].

Physical fitness is divided into two aspects, including: fitness-related health (fitness related fitness) and skill-related fitness [12-14]. Physical fitness related to health includes: 1) cardiac endurance (cardio respiration), 2) muscle strength, 3) muscle endurance, 4) flexibility and 5) body composition. While physical fitness associated with skills are: 1) speed, 2) power, 3) balance, 4) agility, 5) coordination and 6) reaction speed. The understanding of the components of physical fitness [15] can be seen in the table below:

TABLE II. THE COMPONENTS OF PHYSICAL FITNESS

\begin{tabular}{|l|l|}
\hline $\begin{array}{c}\text { Physical } \\
\text { Fitness } \\
\text { Component }\end{array}$ & \multicolumn{1}{c|}{ Definition } \\
\hline Endurance & $\begin{array}{l}\text { The ability of the heart, lungs and blood vessels } \\
\text { to function optimally while performing daily } \\
\text { activities, in a long time without experiencing } \\
\text { significant fatigue }\end{array}$ \\
\hline Strength & $\begin{array}{l}\text { Muscle ability or a group of muscles to perform a } \\
\text { maximum contraction against resistance or load. }\end{array}$ \\
\hline Flexibility & $\begin{array}{l}\text { The ability of joints to perform a movement in } \\
\text { space joint motion to the maximum. }\end{array}$ \\
\hline Speed & Ability to move from one place to another in the \\
\hline
\end{tabular}

\begin{tabular}{|l|l|}
\hline & shortest possible time \\
\hline Power & $\begin{array}{l}\text { Combined between force and speed or maximum } \\
\text { muscle force deployment with maximum speed }\end{array}$ \\
\hline Agility & $\begin{array}{l}\text { Ability to change the direction or position of the } \\
\text { body quickly done together with other } \\
\text { movements. }\end{array}$ \\
\hline Balance & $\begin{array}{l}\text { Ability to maintain posture and body position } \\
\text { quickly on a stand (static balance) or at the time } \\
\text { of movement (dynamic balance) }\end{array}$ \\
\hline Coordination & $\begin{array}{l}\text { Ability to perform a movement or work properly } \\
\text { and efficiently. Coordination Ability to perform } \\
\text { movement or work properly and efficiently }\end{array}$ \\
\hline
\end{tabular}

Every new student test, health profile and physical fitness becomes an important factor in student admission in the physical education study program. In 2016 similar studies have been carried out [16]. The purpose of this study is to determine the profile of students so that they can be mapped based on body mass index and physical fitness.

\section{METHOD}

The research method used in this research is survey method with a descriptive data analysis technique percentage. The population in this study are 116 students of physical education program, Universitas Islam 45 Bekasi of the academic year 2017/2018. The sampling technique used random sampling with a number of 77 students. There are several test instruments used in this study. Among them are: (1) body mass index measurement; the formula is: $\mathrm{BMI}$ or IMT $=\mathrm{BB} / \mathrm{TB}^{2}$ [17], (2) sprint 50 meters, (3) Illinois agility run test, (4) sit up, (5) pull up, (6) vertical jump, (7) sit and reach, (8) push up, (9) hand-eye coordination test and (10) bleep test [15]. Technical analyses used are descriptive statistics and percentages.

\section{RESULTS AND DISCUSSION}

Based on the results of research conducted on the profile of body mass index and physical fitness of physical education students, Universitas Islam 45 Bekasi academic year 2017/2018. Then the percentage and frequency distribution based test item can be seen in the table below [18]:

TABLE III. RECAPITUlation OF BMI RESUlt OF PHySICAL StUdENT EDUCATION

\begin{tabular}{|l|l|l|l|}
\hline No & \multicolumn{1}{|c|}{ Category } & \multicolumn{1}{|c|}{ Frequency } & Percentage (\%) \\
\hline 1 & Weight Less & 1 & 1.3 \\
\hline 2 & Normal Weight & 58 & 75.3 \\
\hline 3 & Overweight & 10 & 13 \\
\hline 4 & Obesity & 8 & 10.4 \\
\hline Amount & 77 & 100 \\
\hline
\end{tabular}

Based on table 3, there was one person (1.3\%) in the category of underweight, 58 people $(75.3 \%)$ in the normal weight category, 10 people $(13 \%)$ in obesity category and 8 people $(10.4 \%)$ in the obesity category. 
TABLE IV. THE RESUlt OF SPRINT 50 METERS TEST

\begin{tabular}{|l|l|l|l|}
\hline No & \multicolumn{1}{|c|}{ Category } & Frequency & Percentage (\%) \\
\hline 1 & Very Good & 1 & 1.3 \\
\hline 2 & Good & 32 & 41.6 \\
\hline 3 & Medium & 33 & 42,9 \\
\hline 4 & Less & 8 & 10.4 \\
\hline 5 & Very Less & 3 & 3.9 \\
\hline \multicolumn{2}{|l|}{ Amount } & 77 & 100 \\
\hline
\end{tabular}

Based on Table 4 above, note 50 meters sprint test results of 77 students of which $1(1.3 \%)$ in the good category, 32 $(41.6 \%)$ in the medium category, $33(42.9 \%)$ in the category of less and 3 people $(3.9 \%)$ in very less category.

TABLE V. The RESULT OF ILLINOIS AgILITYRUNTEST

\begin{tabular}{|l|l|l|l|}
\hline No & Category & Frequency & Percentage (\%) \\
\hline 1 & Very Good & 2 & 2.6 \\
\hline 2 & Good & 0 & 0 \\
\hline 3 & Medium & 8 & 10.4 \\
\hline 4 & Less & 7 & 9.1 \\
\hline 5 & Very Less & 60 & 77.9 \\
\hline \multicolumn{2}{|l|}{ Amount } & 77 & 100 \\
\hline
\end{tabular}

Based on table 5 above, the results of Illinois agility run test of 77 students are 2 people $(2.6 \%)$ in the very good category, 8 people $(10.4 \%)$ in the medium category, 7 people $(9.1 \%)$ in category less and 60 people $(77.9 \%)$ in very less category.

TABLE VI. The Result of Sit Up Test

\begin{tabular}{|l|l|l|l|}
\hline No & Category & Frequency & \multicolumn{1}{|c|}{ Percentage (\%) } \\
\hline 1 & Very Good & 4 & 5.2 \\
\hline 2 & Good & 43 & 55.8 \\
\hline 3 & Medium & 29 & 37.7 \\
\hline 4 & Less & 1 & 1.3 \\
\hline 5 & Very Less & 0 & 0 \\
\hline Amount & 77 & 100 \\
\hline
\end{tabular}

Based on table 6 above, the result of sit-up test of 77 students are 4 people $(5.2 \%)$ in the very good category, 43 people $(55.8 \%)$ in the good category, and 29 people $(37.7 \%)$ in category medium, and 1 people $(1.3 \%)$ in category less.

TABLE VII. The Results Of The Arm Muscle Strength

\begin{tabular}{|l|l|l|l|}
\hline No & \multicolumn{1}{|c|}{ Category } & Frequency & $\begin{array}{c}\text { Percentage } \\
(\boldsymbol{\%})\end{array}$ \\
\hline 1 & Very Good & 2 & 2.6 \\
\hline 2 & Good & 0 & 0 \\
\hline 3 & Medium & 0 & 0 \\
\hline 4 & Less & 60 & 77.9 \\
\hline 5 & Very Less & 15 & 19.5 \\
\hline \multicolumn{2}{|l|}{ Amount } & 77 & 100 \\
\hline
\end{tabular}

Based on table 7 above, the results of the arm muscle strength test of 77 students are two people $(2.6 \%)$ in the very good category, 60 people $(77.9 \%)$ in the category of less and 15 people $(19.5 \%)$ in the category very less.
TABLE VIII. VERTICAL JUMP TEST RESUlts

\begin{tabular}{|l|l|l|l|}
\hline No & Category & Frequency & Percentage (\%) \\
\hline 1 & Very Good & 2 & 2.6 \\
\hline 2 & Good & 13 & 16.9 \\
\hline 3 & Medium & 35 & 45.5 \\
\hline 4 & Less & 27 & 35.1 \\
\hline 5 & Very Less & 0 & 0 \\
\hline \multicolumn{2}{|l|}{ Amount } & 77 & 100 \\
\hline
\end{tabular}

Based on table 8 above, it is known that vertical jump test results from 77 students are 2 people $(2.6 \%)$ in very good category, 13 people (16.9\%) in good category, 35 people $(45.5 \%)$ in medium category and 27 people $(35.1 \%)$ in the less category.

TABLE IX. The Result of The Sit AND ReACH TeSt

\begin{tabular}{|l|l|l|l|}
\hline No & \multicolumn{1}{|c|}{ Category } & Frequency & $\begin{array}{c}\text { Percentage } \\
(\%)\end{array}$ \\
\hline 1 & Very Good & 8 & 10.4 \\
\hline 2 & Good & 16 & 20.8 \\
\hline 3 & Medium & 13 & 16.9 \\
\hline 4 & Less & 13 & 16.9 \\
\hline 5 & Very Less & 27 & 35.1 \\
\hline Amount & 77 & 100 \\
\hline
\end{tabular}

Based on table 9, the result of flexibility measurement with sit and reach test of 77 students are 8 people $(10.4 \%)$ in the very good category, 16 people $(20.8 \%)$ in good category, 13 people $(16.9 \%)$ at medium category, 13 people $(16.9 \%)$ in the category of less and 27 people $(35.1 \%)$ in very less category.

TABLE X. The Results of The Push UP Test

\begin{tabular}{|l|l|l|l|}
\hline No & \multicolumn{1}{|c|}{ Category } & Frequency & Percentage (\%) \\
\hline 1 & Very Good & 10 & 13 \\
\hline 2 & Good & 4 & 5.2 \\
\hline 3 & Medium & 10 & 13 \\
\hline 4 & Less & 50 & 64.9 \\
\hline 5 & Very Less & 3 & 3.9 \\
\hline \multicolumn{2}{|l|}{ Amount } & 77 & 100 \\
\hline
\end{tabular}

Based on table 10, the results of the push-up test on 77 students were 10 people $(13 \%)$ in very good category, 4 people $(5.2 \%)$ in good category, 10 people $(13 \%)$ in medium category, 50 people $(64.9 \%)$ in the category of less and 3 people $(3.9 \%)$ in very less category.

TABLE XI. The Results Of The Test Hand-Eye CoOrdination

\begin{tabular}{|l|l|l|l|}
\hline No & Category & Frequency & Percentage (\%) \\
\hline 1 & Very Good & 60 & 77.9 \\
\hline 2 & Good & 0 & 0 \\
\hline 3 & Medium & 2 & 2.6 \\
\hline 4 & Less & 1 & 1.3 \\
\hline 5 & Very Less & 14 & 18.2 \\
\hline Amount & 77 & 100 \\
\hline
\end{tabular}

According to the table 11, the results of the test hand-eye coordination or throwing a ball catch 77 students of which 60 $(77.9 \%)$ in the category very well, $2(2.6 \%)$ in the medium category, $1(1.3 \%)$ in the category of less and 14 people $(18.2 \%)$ in very less category. 
TABLE XII. THE RESUlTS OF BLEEP TEST

\begin{tabular}{|l|l|l|l|}
\hline No & \multicolumn{1}{|c|}{ Category } & Frequency & Percentage (\%) \\
\hline 1 & Very Good & 3 & 3.9 \\
\hline 2 & Good & 0 & 0 \\
\hline 3 & Medium & 32 & 41.6 \\
\hline 4 & Less & 2 & 2.6 \\
\hline 5 & Very Less & 40 & 51.9 \\
\hline \multicolumn{2}{|l|}{ Amount } & 77 & 100 \\
\hline
\end{tabular}

Based on table 12, the results of cardiorespiratory endurance test with bleep test on 77 students were 3 people $(3.9 \%)$ in very good category, 32 people $(41.6 \%)$ in medium category, 2 persons $(2.6 \%)$ in less category and 40 people $(51.9 \%)$ in very less category.

TABLE XIII. ReCAPItUlation of The ENTIRe Physical Fitness Test

\begin{tabular}{|l|l|l|}
\hline No & \multicolumn{1}{|c|}{ Category } & \multicolumn{1}{c|}{ Percentage (\%) } \\
\hline 1 & Very Good & 13.28 \\
\hline 2 & Good & 15.58 \\
\hline 3 & Medium & 23.38 \\
\hline 4 & Less & 24.39 \\
\hline 5 & Very Less & 23.38 \\
\hline Amount & 100 \\
\hline
\end{tabular}

Based on summary and recapitulation of physical fitness test result showed that $13.28 \%$ of students were in very good category, $15.58 \%$ in good category, $23.38 \%$ in medium category, 24.39 in the less category, and $23.38 \%$ in category is very less. For the percentage can be seen in the graph below:

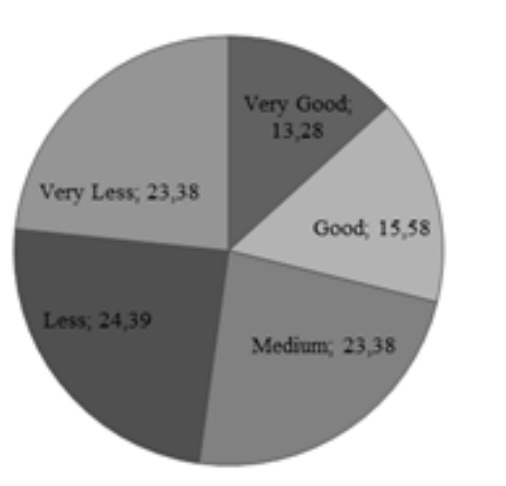

Fig. 1. Percentage of recapitulation result of physical fitness test.

Physiological testing is commonly used to assess the overall fitness level of the athletes and to set guidelines for individualized training $[19,20]$. Based on the results of research and descriptive analysis can be seen that the state of physical fitness physics education students of Islamic University 45 Bekasi 2017/2018 majority are in the category of moderate, less, and very less. This results almost the same as the previous two years [16].

Body mass index measurement is dominant in the normal category. There is one test that is the greatest percentage in very good category, that is hand-eye coordination test. While the two types of tests that percentage included in either category that is on sit-up test and flexibility (sit and reach test). The dominant test items in the less category are the push up, vertical jump and bleep tests and those in the very poor category are the illinois agility run test and the pull up test.

Physical fitness is a unified whole of some components that cannot be separated just like that, either upgrading or maintenance. Physical fitness includes various body systems, namely: muscular system (muscular), nervous system (nervorum), skeletal system, respiration system, cardio system kidney (excretion) and cooperation between various systems holistically [21].

In fact physical fitness is a certain dynamic degree that is expected to face the demands of work and still have energy reserves to do other physical tasks [21]. The degree of maximal physical fitness, it is possible to minimize a person suffering from the chronic-degenerative disease at the age of old and still productive in old age [22]. Therefore, it takes coaching and maintenance of one's physical fitness. For the successful implementation of the task, there needs to be a match between the requirements that must be met that is anatomical and physiological to the kind of intensity of physical tasks that must be implemented. Thus the fitness that should be owned by a freshman is with good category, even if possible in the very good category. This is much needed because of the many practice courses that require excellent fitness levels. If not, then many students who will trouble in college, even fall ill when they in a day should get 2 to 3 times.

Some factors can influence physical condition that is exercise, the principle of overload, rest, healthy life habit, environmental, and also a factor of food and nutrition [23]. Exercise is one factor that can affect one's physical fitness level. With regular exercise will improve cardiovascular endurance and can also reduce the fat in the body, which means that all organs are trained regularly can adapt to the course. Also, the implementation of a diet that meets the requirements of healthy food is one of the efforts to improve good body condition is needed by the body. Because with the healthy food the body's nutritional needs will be met. With the fulfilment of body nutrition to eat the condition of the body will always be healthy, not easily tired, easily drowsy, or susceptible to disease.

With the reality already faced that the physical test results of new admissions year 2017/2018 who have a level of fitness between medium, less, and very less. Based on that it is necessary to approach the learning and training methods that will be applied by the lecturers especially subject theory and practice courses, using the approach of learning and training methods appropriate so that will help students in improving fitness gradually making it possible to achieve good physical fitness and improve student performance.

\section{CONCLUSION}

Based on the results of the calculation and data analysis it can be concluded that: (1) IMT test results showed 1 or $1.3 \%$ of students who are in the category weight less, 58 or $75.3 \%$ of students in the category of normal weight, 10 or $13 \%$ students in the category of overweight and 8 or $10.4 \%$ of students in the obesity category, (2) Physical fitness test results showed that $13.28 \%$ in the very good category, $15.58 \%$ in good category, 
[11] M. Fogelholm, S. Stigman, T. Huisman and J. Metsämuuronen, "Physical fitness in adolescents with normal weight and overweight," Scandinavian journal of medicine \& science in sports, vol. 18(2), pp. 162-170, 2008. and $23.38 \%$ in very less category.

\section{ACKNOWLEDGMENT}

This research was supported by our colleagues Universitas Islam 45 Bekasi and Post Graduate Program, the Universitas Negeri Jakarta who provided insight and expertise that greatly assisted the research.

\section{REFERENCES}

[1] "Peraturan Pemerintah Republik Indonesia Nomor 66 Tahun 2010 tentang Perubahan Atas Peraturan Pemerintah Nomor 17 Tahun 2010 tentang Pengelolaan dan Pelaksanaan Pendidikan," .

[2] "Peraturan Menteri Pendidikan Nasional Nomor 34 Tahun 2010 tentang Pola Penerimaan Mahasiswa Baru," .

[3] WHO, "Obesity and overweight: Fact sheet," 2016.

[4] N. National Obesity Observatory, "Body Mass Index as a measure of obesity," Natl. Heal. Serv., 2009.

[5] P.T. James, R. Leach, E. Kalamara, and M. Shayeghi, "The worldwide obesity epidemic.," Obesity research. 2001.

[6] W.H. Organization, Media centre obesity and overweight. World Health, 2016.

[7] R.P. Wilder, J.A. Greene, K.L. Winters, W.B. Long, K.D. Gubler and R.F. Edlich, "Physical fitness assessment: An update," Journal of LongTerm Effects of Medical Implants, 2006

[8] F.B. Ortega, J.R. Ruiz, M.J. Castillo and M. Sjöström, "Physical fitness in childhood and adolescence: A powerful marker of health," International Journal of Obesity, 2008.

[9] J. Brisswalter, M. Collardeau and A. René, "Effects of acute physical exercise characteristics on cognitive performance," Sports medicine, vol. 32(9), pp. 555-566, 2002.

[10] F.B. Ortega, E.G. Artero, J.R. Ruiz, V. España-Romero, D. JiménezPavón, G. Vicente-Rodríguez and D. Ciarapica, "Physical fitness levels among European adolescents: the HELENA study," British journal of sports medicine, vol. 45(1), pp. 20-29, 2011.

[12] C.B. Corbin, R.P. Pangrazi and B.D. Franks, Definitions: Health, Fitness, and Physical Activity. Pres. Counc. Phys. Fit. Sports Res. Dig., 2000.

[13] J.J. Smith, N. Eather, P.J. Morgan, R.C. Plotnikoff, A.D. Faigenbaum and D.R. Lubans, "The health benefits of muscular fitness for children and adolescents: a systematic review and meta-analysis," Sports medicine, vol. 44(9), pp. 1209-1223, 2014.

[14] J.C. Hannon, B.J. Holt and J.D. Hatten, "Personalized systems of instruction model: Teaching health-related fitness content in high school physical education," Journal of Curriculum and Instruction, vol. 2(2), pp. 20-33, 2008.

[15] Widiastuti, Tes dan Pengukuran Olahraga. Jakarta: Rajagrafindo, 2015.

[16] A. Haqiyah, "Profil Indeks Massa Tubuh dan Tingkat Kebugaran Jasmani Mahasiswa PJKR Universitas Islam 45 Bekasi Tahun 2015/2016," pp. 24-36, 2016.

[17] J.S. Markowitz, "Body mass index (BMI)," in SpringerBriefs in Public Health, 2018.

[18] H. Muhamad, Memet, Aridhotul, Diktat statistik olahraga. FKIP: UNISMA Bekasi, 2015

[19] N.G. Little, "Physical performance attributes of Junior and Senior women, Juvenile, Junior and Senior men judokas," J Sports Med Phys Fitness, vol. 31, pp. 510-520, 1991.

[20] W.D. McArdle, F.I. Katch, V.L. Katch, Exercise physiology: Energy, nutrition and human performance, 5th ed., Linppincott, Williams \& Wilkins, 2003.

[21] D. L. Badriah, Fisiologi Olahraga Edisi II. Bandung: Multazam, 2009.

[22] C. Dirtu, C. Soponaru, M. Butnaru, and M. Iorga, Physical Activity in the Chronically-ill Elderly: A Review, in Rethinking Social Action. Core Values, 2015.

[23] M.A. Nasution, U.N. Surabaya, F.I. Keolahragaan, J. Pendidikan, and K. Dan, "Tingkat Kondisi Fisik Atlet Putra Tim Bolabasket SMAN 1 Driyorejo Kabupaten Gresik Tahun 2013,” 2014. 